\title{
Interleukin-10 production at the early stage of infection with foot-and-mouth disease virus related to the likelihood of persistent infection in cattle
}

\author{
Zhidong Zhang ${ }^{1,2^{*}}$, Claudia Doel ${ }^{2,3}$ and John B. Bashiruddin ${ }^{2,4}$
}

\begin{abstract}
The factors leading to persistent infection of foot-and-mouth disease (FMD) virus in ruminants are not well defined. This paper provides evidence of the presence of interleukin-10 (IL-10) early in the course of infection (1-4 days) as a factor in the development of persistence of FMD virus in cattle. Results showed that serum IL-10 in carrier cattle infected with FMD virus type $O(n=4)$ was detected and peaked at 1 or 2 days post infection and rapidly declined thereafter. In contract, serum IL-10 levels in non-carrier cattle $(n=21)$ were very low or undetectable during the same period.
\end{abstract}

\section{Introduction, methods and results}

Foot-and-mouth disease (FMD) virus is a small, nonenveloped single stranded, positive sense RNA virus (Picornaviridae family) and has seven serotypes: O, A, C, Asia 1, and Southern African Territories (SAT) 1, 2 and 3 , all of which cause a highly contagious vesicular disease in cloven-hoofed animals [1]. After the acute phase of infection, which may be associated with clinical disease or with asymptomatic infection, up to $50 \%$ of FMD virus-infected cattle and other bovids may carry the virus in their pharyngeal regions for months or years without showing any clinical signs of disease, and may be critical to the epidemiology of FMD, at least at the wildlife domestic cattle interface (reviewed in [1, 2]). Carrier animals are defined as persistently infected animals from which FMD virus can be recovered from esophagealpharyngeal fluid (Probang) for more than 28 days after infection [3]. FMD virus is eventually eliminated from carriers. However, the host factors that enable persistence or elimination are not known. Previous studies

\footnotetext{
*Correspondence: zhangzhidong@caas.cn

${ }^{1}$ State Key Laboratory of Veterinary Etiological Biology, Lanzhou Veterinary Research Institute, Xujiaping 1, Lanzhou 730046, Gansu, China Full list of author information is available at the end of the article
}

showed that the persistence with FMD virus was less likely to be established if the immune response to vaccination had developed sufficiently [4] and the rate of clearance of FMD virus from the pharyngeal region may be related to the likelihood of persistence $[5,6]$. Recent studies have shown that FMD virus-induced immunosuppression during the acute stage of infection is not due to infection of the lymphocytes [7] but lack of T cell responsiveness via interleukin-10 (IL-10) signalling [8]. IL-10 is an immunoregulatory cytokine that can modulate immune processes associated with the anti-inflammatory response and the inhibition of cellular responses via a variety of mechanisms. It has been demonstrated that elevated levels of IL-10 production are associated with persistent infection with hepatitis $\mathrm{C}$ virus $(\mathrm{HCV})$ [9, 10], HIV [11-13], Epstein-Barr virus [14] and lymphocytic choriomeningitis virus (LCMV) $[15,16]$. Interferons (IFN) are known to have antiviral activity and are considered to be important in the initial host cell defence against virus infection. It has been demonstrated that replication of FMD virus is highly sensitive to type I and II IFNs and that porcine or bovine IFN added to supernatants of cell cultures inhibits FMD virus replication in vitro $[17,18]$ and clears FMD virus from persistently-infected cells [18]. The aim of the current study 
was to define the early IL-10 and IFN responses of cattle infected with the type O FMD virus and its relationship to the persistence of FMD virus.

To address this, serum samples collected at $0,1,2,3$, and 4 days post-infection (dpi) from 15 cattle of varying ages infected with the type O UKG/34/2001 virus and similarly from ten cattle infected with the type O SKR/1/2000 virus were used for detection of IL-10 and IFN protein. Detailed results regarding the clinical profiles are presented elsewhere [5, 6]. Briefly, all inoculated animals showed clinical signs of FMD with the development of fever and vesicles on all feet, and tongue. Viraemia peaked at $2-3 \mathrm{dpi}$, which was cleared by day 4 in all animals. All cattle had specific virus in their Probang samples for at least 7 days after virus exposure which was cleared from the pharynx at different rates. Four out of 25 cattle became carrier animals as evidenced by virus in their Probang samples after 28 dpi and later. The remaining 21 cattle did not develop the carrier state (Table 1). Statistical analyses were carried out by using a non-parametric test (independent samples t test using Excel). $P<0.05$ was considered statistically significant.
To analyze differences in humoral responses between carriers $(n=4)$ and non-carriers $(n=21)$, IgG antibodies to the structural proteins of FMD virus were quantified in sera using liquid phase blocking ELISA (LPBE) as described previously [19]. Antibody titre of $<1: 45$ is considered as negative. As shown in (Table 2), the cohort $(n=15)$ infected with the type O UKG/34/2001 had seroconverted to be FMD positive. Type-specific antibodies were detected in all inoculated animals by $4 \mathrm{dpi}$ (Table 2) and in the majority of contact animals (VD36, VD37, VD42, VD43, VD46, VD47, VD50) by $6 \mathrm{dpi}$ (Table 2). There are no significant difference in levels of serum IgG antibodies to the structural proteins of FMD virus between carrier cattle and non-carrier animals $(p=0.44, p>0.05)$. Similar results were also observed in sera collected from the cohort infected with the type $\mathrm{O}$ SKR isolate (data not shown). The results obtained suggest that the IgG antibody response to structural proteins of FMD virus is not associated with the development of persistence in cattle, which is consistent with previous reports [1].

To investigate if elevation of serum IL-10 during the acute infection correlates with development of persistent

Table 1 Cattle infected with foot-and-mouth disease virus were used in this study.

\begin{tabular}{|c|c|c|c|c|}
\hline Animal ID & Age (days) & Route of infection & Carrier Status & Virus \\
\hline VD34 & 273 & Subepidermo-lingual & Non-carrier & FMDV O UKG34/2001 \\
\hline VD35 & 335 & Subepidermo-lingual & Non-carrier & FMDV O UKG34/2001 \\
\hline VD40 & 243 & Subepidermo-lingual & Carrier & FMDV O UKG34/2001 \\
\hline VD41 & 304 & Subepidermo-lingual & Carrier & FMDV O UKG34/2001 \\
\hline VD44 & 91 & Subepidermo-lingual & Non-carrier & FMDV O UKG34/2001 \\
\hline VD45 & 91 & Subepidermo-lingual & Non-carrier & FMDV O UKG34/2001 \\
\hline VD48 & 91 & Subepidermo-lingual & Non-carrier & FMDV O UKG34/2001 \\
\hline VD49 & 91 & Subepidermo-lingual & Non-carrier & FMDV O UKG34/2001 \\
\hline VD36 & 335 & Direct contact & Non-carrier & FMDV O UKG34/2001 \\
\hline VD37 & 243 & Direct contact & Non-carrier & FMDV O UKG34/2001 \\
\hline VD42 & 243 & Direct contact & Non-carrier & FMDV O UKG34/2001 \\
\hline VD43 & 213 & Direct contact & Non-carrier & FMDV O UKG34/2001 \\
\hline VD46 & 91 & Direct contact & Non-carrier & FMDV O UKG34/2001 \\
\hline VD47 & 91 & Direct contact & Non-carrier & FMDV O UKG34/2001 \\
\hline VD50 & 91 & Direct contact & Non-carrier & FMDV O UKG34/2001 \\
\hline VI56 & 274 & Subepidermo-lingual & Carrier & FMDV O SKR 2000 \\
\hline VI57 & 152 & Subepidermo-lingual & Non-carrier & FMDV O SKR 2000 \\
\hline VI58 & 274 & Subepidermo-lingual & Carrier & FMDV O SKR 2000 \\
\hline VI59 & 274 & Direct contact & Non-carrier & FMDV O SKR 2000 \\
\hline VI60 & 152 & Direct contact & Non-carrier & FMDV O SKR 2000 \\
\hline VI61 & 152 & Subepidermo-lingual & Non-carrier & FMDV O SKR 2000 \\
\hline VI62 & 152 & Subepidermo-lingual & Non-carrier & FMDV O SKR 2000 \\
\hline VI63 & 152 & Direct contact & Non-carrier & FMDV O SKR 2000 \\
\hline VI64 & 274 & Direct contact & Non-carrier & FMDV O SKR 2000 \\
\hline VI65 & 274 & Direct contact & Non-carrier & FMDV O SKR 2000 \\
\hline
\end{tabular}


Table 2 Antibody response in cattle infected with foot-and-mouth disease virus.

\begin{tabular}{|c|c|c|c|c|c|c|c|c|c|c|c|c|}
\hline \multirow[t]{2}{*}{ Animal ID } & \multicolumn{12}{|c|}{ Days post inoculation } \\
\hline & 0 & 1 & 2 & 3 & 4 & 5 & 6 & 7 & 9 & 15 & 21 & 28 \\
\hline VD34 & Neg & Neg & Neg & Neg & 128 & 1448 & $\geq 2896$ & $>2048$ & $\geq 2896$ & $\geq 2896$ & $>2048$ & $>2048$ \\
\hline VD35 & Neg & Neg & Neg & Neg & 362 & $\geq 2896$ & $\geq 2896$ & $>2048$ & & & & \\
\hline VD40 & Neg & Neg & Neg & Neg & 128 & 1024 & 1448 & $>2048$ & 1448 & 1448 & 1448 & 1448 \\
\hline VD41 & Neg & Neg & Neg & Neg & 90 & 1448 & 1448 & $>2048$ & 1448 & 2048 & $>2048$ & $>2048$ \\
\hline VD44 & Neg & Neg & Neg & 45 & 1024 & $\geq 2896$ & $\geq 2896$ & $>2048$ & 1448 & $\geq 2896$ & $>2048$ & $>2048$ \\
\hline VD45 & Neg & Neg & Neg & Neg & 128 & 1448 & 1448 & $>2048$ & 1448 & 2048 & $>2048$ & $>2048$ \\
\hline VD48 & Neg & Neg & Neg & Neg & 128 & $\geq 2896$ & $\geq 2896$ & $>2048$ & $\mathrm{ND}$ & $\mathrm{ND}$ & $>2048$ & $>2048$ \\
\hline VD49 & Neg & Neg & Neg & Neg & 45 & Neg & 1024 & $>2048$ & & & & \\
\hline VD36 & Neg & Neg & Neg & Neg & Neg & Neg & 362 & 1448 & & & & \\
\hline VD37 & Neg & Neg & Neg & Neg & Neg & Neg & 512 & 1448 & 2048 & $\geq 2896$ & $>2048$ & $>2048$ \\
\hline VD42 & Neg & Neg & Neg & Neg & Neg & Neg & 724 & $>2048$ & $\geq 2896$ & $\geq 2896$ & $>2048$ & $>2048$ \\
\hline VD43 & Neg & Neg & Neg & Neg & Neg & Neg & 256 & 2048 & 1448 & $\geq 2896$ & 2048 & 1148 \\
\hline VD46 & Neg & Neg & Neg & Neg & Neg & 1448 & Neg & Neg & 90 & $\geq 2896$ & $>2048$ & \\
\hline VD47 & Neg & Neg & Neg & Neg & Neg & Neg & Neg & Neg & Neg & 1024 & $>2048$ & $>2048$ \\
\hline VD50 & Neg & Neg & Neg & Neg & Neg & Neg & Neg & 362 & 2048 & $\geq 2896$ & & \\
\hline
\end{tabular}

infection in cattle, IL-10 was measured basically following the method of Kwong et al. [20]. Briefly, enzymelinked immunosorbent assay (ELISA) plates were coated with anti-IL-10 and each cattle serum was tested in duplicate. The assay was repeated three times. As shown in Figure 1, the elevation of serum IL-10 during the acute phase of FMD virus infection with either type O UKG or type O SKR isolates (from 1 to $4 \mathrm{dpi}$ ) was only observed in sera collected from carrier cattle $(n=4)$. In the carrier group, serum IL-10 was detected and peaked at 1 or $2 \mathrm{dpi}$ and rapidly declined afterwards. In contrast, it was evident that levels of IL-10 in sera from the non-carrier group $(n=21)$ were much lower or undetectable. Comparison of serum IL-10 levels between carrier and noncarrier cattle showed that levels from carrier cattle during early infection were significantly higher than in non-carrier animals $(p=0.025, p<0.05)$, suggesting an association of IL-10 response during the acute phase of infection with a common outcome of FMD disease (i.e. persistence) in cattle. Age at infection is known to influence the establishment of viral persistence [21,22] and bacterial infection [23]. It has also been shown that infected calves (4-9 weeks of age) with FMD virus did not always developed clearly visible clinical signs of FMD [24] as observed in infected adult cattle. Interestingly, persistent infection was previously reported to only occur in a group of cattle which is older than 8 months at infection [25]. Similar observation was found in this study. No animal at age of younger than 6 months at infection $(n=12)$ became carrier (Table 1), which is correlated with the observations that no elevation of serum IL-10 during the acute phase of FMD virus infection with either type O UKG or type O SKR isolates (from 1 to $4 \mathrm{dpi}$ ), IL-10 ranging from $-0.07 \pm 0.21$ to $-0.08 \pm 0.12$ was observed in sera collected from these young animals, further suggesting IL-10 as a contributing factor in the likelihood of persistence of FMD virus. In contrast, when the IFN-gamma response was tested using the same serum samples, the results did not correlate with the outcome of disease (i.e. carrier or non-carrier) although increases in levels of serum IFN-gamma occurred in some animals after infection (data not shown).

\section{Discussion}

The results obtained in this study suggest that the humoral IgG response to structural proteins of FMD virus is not associated with the development of persistence in cattle, however, the previous study showed that persistence with FMD virus was less likely to be established if effective immune response to vaccination had developed [4]. IL-10 is an immunoregulatory cytokine which is widely acknowledged to contribute to the inhibition of immune responses via a variety of mechanisms. Many studies with other viruses have indicated that IL-10 initiates $\mathrm{T}$ cell inactivation during viral infection and have concluded that this can lead to viral persistence $[1,9-16]$. The present paper provides evidence of the association of IL-10 response during the acute phase of infection with a common outcome of FMD disease (i.e. persistence) in cattle. Although much is still unclear how IL-10 regulates the host immune response, it is possible that the relatively high IL-10 response causes a delay in or 


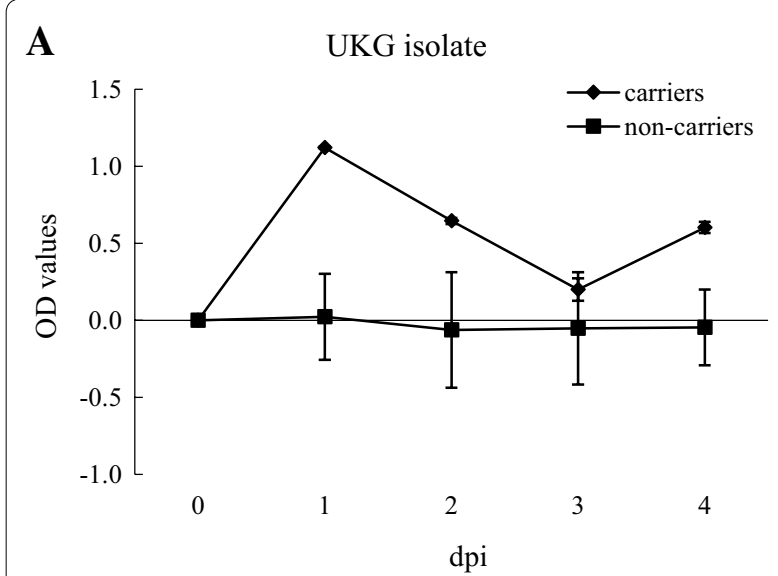

B

SKR isolate

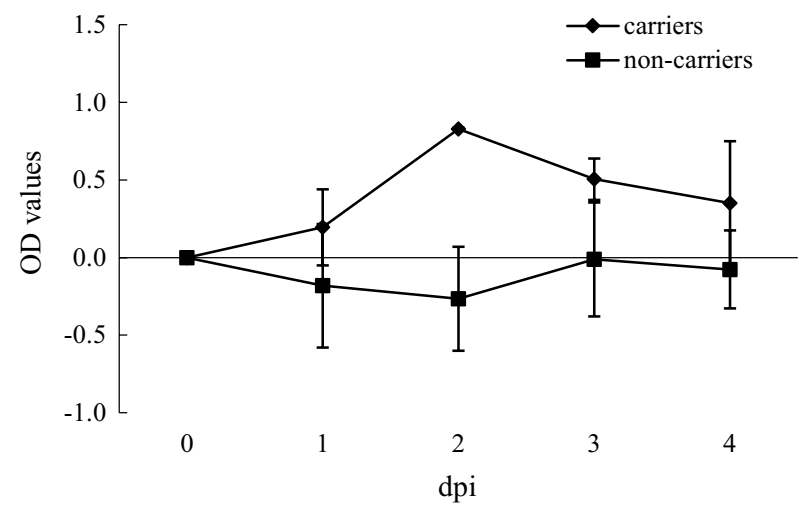

Figure 1 Interleukin-10 (IL-10) in sera of cattle during the acute phase of FMD virus infection. 25 cattle were assayed for circulating IL-10 by ELISA from day 0 to day 4 post infection. A Two carrier cattle and 13 non-carrier cattle infected with FMD virus O UKG34/2001; B Two carrier cattle and eight non-carrier cattle infected with FMD virus O SKR/2000; Error bars show STDEV of the mean.

the inhibition of both the type-1 response and T cell activation until it is "too late" to arrest the disease process, resulting in incomplete clearance of clearing the virus, leading to the persistence. Of course, extrapolation of the results from this study on cattle is always questionable because persistence with FMD virus also occurs in small ruminants [1]. Furthermore, the elevation of serum IL-10 levels raises the question of why IL-10 induction did not occur in all infected cattle and whether IL-10 is the only member of this cytokine family that could influence the outcome of infection with FMD virus. The apparent relationship between the development of the carrier state and IL-10 response prompts further investigation.

\section{Abbreviations}

FMD: foot-and-mouth disease; IL-10: interleukin-10; ELISA: enzyme-linked immunosorbent assay; dpi: days post-infection; IFN: interferon.

\section{Competing interests}

The authors declare that they have no competing interests.

\section{Author details}

${ }^{1}$ State Key Laboratory of Veterinary Etiological Biology, Lanzhou Veterinary Research Institute, Xujiaping 1, Lanzhou 730046, Gansu, China. ${ }^{2}$ The Pirbright Institute, Ash Road, Pirbright, Woking, Surrey GU24 ONF, UK. ${ }^{3}$ DCD Consulting Ltd, Alton, Hants GU34 5BG, UK. ${ }^{4}$ JBBiologik, Farnham, Surrey GU10 1DH, UK.

\section{Authors' contributions}

ZZ designed the study, drafted the manuscript and participated in all tests. $C D$ verified design, participated in all tests and JB drafted the manuscript. JB participated in some of tests and drafted the manuscript. All authors read and approved the final manuscript.

\section{Acknowledgements}

This work was partially supported by a China Partnership Award of the Biotechnology and Biological Sciences Research Council, United Kingdom.

Received: 1 April 2015 Accepted: 9 October 2015

Published online: 19 November 2015

\section{References}

1. Alexandersen S, Zhang Z, Donaldson Al, Garland AJ (2003) The pathogenesis and diagnosis of foot-and-mouth disease. J Comp Pathol 129:1-36

2. Jori F, Caron A, Thompson PN, Dwarka R, Foggin C, de Garine-Wichatitsky M, Hofmeyr M, Van Heerden J, Heath L: Characteristics of foot-and-mouth disease viral strains circulating at the wildlife/livestock interface of the great limpopo transfrontier conservation area. Transbound Emerg Dis, in press

3. Salt JS (1993) The carrier state in foot and mouth disease - an immunological review. Br Vet J 149:207-223

4. Doel TR, Williams L, Barnett PV (1994) Emergency vaccination against foot-and-mouth disease: rate of development of immunity and its implications for the carrier state. Vaccine 12:592-600

5. Zhang Z, Murphy C, Quan M, Knight J, Alexandersen S (2004) Extent of reduction of foot-and-mouth disease virus RNA load in oesophagealpharyngeal fluid after peak levels may be a critical determinant of virus persistence in infected cattle. J Gen Virol 85:415-421

6. Zhang Z, Alexandersen S (2004) Quantitative analysis of foot-and-mouth disease virus RNA loads in bovine tissues: implications for the site of viral persistence. J Gen Virol 85:2567-2575

7. Bautista EM, Gregg D, Golde WT (2002) Characterization and functional analysis of skin-derived dendritic cells from swine without a requirement for in vitro propagation. Vet Immunol Immunopathol 88:131-148

8. Diaz-San Segundo F, Rodriguez-Calvo T, de Avila A, Sevilla N (2009) Immunosuppression during acute infection with foot-and-mouth disease virus in swine is mediated by IL-10. PLoS One 4:e5659

9. Woitas RP, Petersen U, Moshage D, Brackmann HH, Matz B, Sauerbruch T, Spengler U (2002) HCV-specific cytokine induction in monocytes of patients with different outcomes of hepatitis C. World J Gastroenterol 8:562-566

10. Accapezzato D, Francavilla V, Paroli M, Casciaro M, Chircu LV, Cividini A, Abrignani S, Mondelli MU, Barnaba V (2004) Hepatic expansion of a virusspecific regulatory $C D 8(+) T$ cell population in chronic hepatitis $C$ virus infection. J Clin Invest 113:963-972

11. Zanussi S, Simonelli C, D'Andrea M, Caffau C, Clerici M, Tirelli U, DePaoli P (1996) CD8+lymphocyte phenotype and cytokine production in longterm non-progressor and in progressor patients with HIV-1 infection. Clin Exp Immunol 105:220-224

12. Clerici M, Fusi ML, Ruzzante S, Piconi S, Biasin M, Arienti D, Trabattoni D, Villa M (1997) Type 1 and type 2 cytokines in HIV infection-a possible role in apoptosis and disease progression. Ann Med 29:185-188

13. Orandle MS, Williams KC, MacLean AG, Westmoreland SV, Lackner AA (2001) Macaques with rapid disease progression and simian immunodeficiency virus encephalitis have a unique cytokine profile in peripheral lymphoid tissues. J Virol 75:4448-4452 
14. Swaminathan S (2003) Molecular biology of Epstein-Barr virus and Kaposi's sarcoma-associated herpesvirus. Semin Hematol 40:107-115

15. Ejrnaes M, Filippi CM, Martinic MM, Ling EM, Togher LM, Crotty S, von Herrath MG (2006) Resolution of a chronic viral infection after interleukin-10 receptor blockade. J Exp Med 203:2461-2472

16. Brooks DG, Trifilo MJ, Edelmann KH, Teyton L, McGavern DB, Oldstone MB (2006) Interleukin-10 determines viral clearance or persistence in vivo. Nat Med 12:1301-1309

17. Chinsangaram J, Koster M, Grubman MJ (2001) Inhibition of L-deleted foot-and-mouth disease virus replication by alpha/beta interferon involves double-stranded RNA-dependent protein kinase. J Virol 75:5498-5503

18. Zhang ZD, Hutching G, Kitching P, Alexandersen S (2002) The effects of gamma interferon on replication of foot-and-mouth disease virus in persistently infected bovine cells. Arch Virol 147:2157-2167

19. Ferris NP, Kitching RP, Oxtoby JM, Philpot RM, Rendle R (1990) Use of inactivated foot-and-mouth disease virus antigen in liquid-phase blocking ELISA. J Virol Methods 29:33-41

20. Kwong LS, Hope JC, Thom ML, Sopp P, Duggan S, Bembridge GP, Howard CJ (2002) Development of an ELISA for bovine IL-10. Vet Immunol Immunopathol 85:213-223
21. Edmunds WJ, Medley GF, Nokes DJ, Hall AJ, Whittle HC (1993) The influence of age on the development of the hepatitis B carrier state. Proc Biol Sci 253:197-201

22. Shimakawa Y, Yan HJ, Tsuchiya N, Bottomley C, Hall AJ (2013) Association of early age at establishment of chronic hepatitis B infection with persistent viral replication, liver cirrhosis and hepatocellular carcinoma:a systematic review. PLoS One 8:e69430

23. Windsor PA, Whittington RJ (2010) Evidence for age susceptibility of cattle to Johne's disease. Vet J 184:37-44

24. Bouma A, Dekker A, de Jong MC (2004) No foot-and-mouth disease virus transmission between individually housed calves. Vet Microbiol 98:29-36

25. Bashiruddin JB, Zhang Z, Doel C, Horsington J, Alexandersen S (2004) The relationship between age and the likelihood of persistence in FMDV infected cattle. Session of research group of the standing technical committee of the EUFMD. October 2004. The EUFMD, Crete, Greece, pp 403-405

\section{Submit your next manuscript to BioMed Central and take full advantage of:}

- Convenient online submission

- Thorough peer review

- No space constraints or color figure charges

- Immediate publication on acceptance

- Inclusion in PubMed, CAS, Scopus and Google Scholar

- Research which is freely available for redistribution

Submit your manuscript at

www.biomedcentral.com/submit

C Biomed Central 